\title{
The influence of natrural fermentation on coffee drink quality
}

\author{
Leandro Ferreira Bernardes Pereira ${ }^{1}$ (D), Kleso Silva Franco Junior ${ }^{1}$ (D), Camila Karen Reis Barbosa ${ }^{1}$ (D)
}

${ }^{1}$ Centro Superior de Ensino e Pesquisa de Machado/CESEP, Machado, MG, Brasil

Contact authors: sorrisolfbp@hotmail.com, kleso.junior@yahoo.com.br, camilakarenr@gmail.com

Received in November 13, 2019 and approved in March 10, 2020

\begin{abstract}
Coffee quality refers to various methods used in farming, selective harvesting that assist in quality preservation and drying methods to be performed. Some drying methods that are being performed fermentation procedures have helped in obtaining specialty coffees. The objective of the research was to evaluate the effects of controlled natural fermentation of coffee through the temperature and time and its influence on the quality of coffee, according to the prescribed attributes in SCAA methodology, the type of coffee drink and time for drying grain. The research was carried out at Lavrinha farm, located at Poço Fundo (south of Minas Gerais), with coffee fruits of Catuaí Vermelho IAC 144 cultivar and selective and manual harvesting. The treatments with temperature-controlled fermentation of 30 and $40{ }^{\circ} \mathrm{C}(1,2,3,6$ and 12 hours) and the control treatment were used with three replications in a randomized block system (DBC) in a factorial scheme. After fermentation, the batches were dried to $11.5 \%$ humidity and evaluated according to the SCAA (2015) methodology. The natural fermentation induced by temperature $\left({ }^{\circ} \mathrm{C}\right.$ ) and time (hours) directly influenced the drink quality, resulting in a coffee with a score of 82 to 84 points, with attribute aggregation and special classification. Natural fermentation with temperature up to $40{ }^{\circ} \mathrm{C}$ and time control of 3,1 and 24 hours resulted in an improvement in coffee quality by 84 points.
\end{abstract}

Key words: Control; Drying; Harvest; Monitoring.

\section{INTRODUCTION}

The coffee consumer market is directly related to the high demand for high-quality coffees, the so-called "specialty coffees", being observed for both domestic and foreign markets, with Brazil being the largest exporter and coffee producer in the world. According to Borém et al (2006), there are several drying methods to obtain quality coffee, but some of them provide a fermentation to the coffee bean that enables the improvement of the beverage quality. Some drying using pulped coffee may produce a fermentation containing phenolic acids, contributing to the quality of the coffee beverage.

Specialty coffees require different management techniques and systems, which associated with field conditions influence the final quality of the product. The improvement of coffee management occurs when selective harvesting with only parchment coffee is performed, the stage where coffee expresses its maximum quality vigor. Selective harvesting helps to increase productivity and quality, this procedure influences a special coffee. After harvesting, a good drying will contribute to an increase in quality, with different aromas and flavors (Pimenta, 2005).

According to Teixeira (2015), coffee quality is related to all practices performed in the field, but the main care that is offered to coffee for quality control should take place after harvest, when drying practices and managements that may influence directly or indirectly in quality.

The practices used in drying the beans to obtain specialty coffees may be linked to fermentation, which consists of a chemical change in the grain providing an aggregation of different aromas and flavors (Chalfoun; Fernandes, 2013). Some methods applied in wet systems, perform a controlled fermentation methodology, contributing to the quality improvement.

Currently, there are two methods of fermentation, the anaerobic using yeast and/or enzyme in the wet process, and the dry aerobic fermentation, in which the presence of oxygen contributes to maximizing the growth of microorganisms responsible for the enzymatic process, in this case, greater control of fermentation is required. To determine the quality of coffee, sensory analysis or cup testing are needed.

According to Rufino et al. (2015), cup testing is necessary to determinate and evaluate some sensorial characteristics as aroma and flavors. The taste rating on the cup tasting may include strictly soft, soft, barely soft, hard, rioysh, rio and rio zona. To determine the classification, soft drink is a reference for all characteristics of the SCAA methodology.

Coffee was introduced in Brazil in 1927 when it arrived in Belém do Pará, and then later it was spread throughout the northern region and in several other states of the country (MAPA, 2018). Currently, cultivation is one of the main responsible for the income of the coffee families in several municipalities.

In the 1990s, Brazil was known abroad as a major exporter of coffee (Alessandro, 2015), but the good quality was not recognized as specific management was not employed to preserve quality. After that, there has been a growing advance in new harvesting and postharvest practices, which has enabled producers to improve coffee quality. 
Coffee value is based on quality (Malta et al., 2008) low quality products may have a price devaluation of around $10 \%$ to $20 \%$, so, for an adequate remuneration, the production of high-quality coffees is essential. The objective of the research was to evaluate the effects of controlled natural fermentation of coffee through the temperature and time and its influence on the quality of coffee, according to the prescribed attributes in SCAA methodology, the type of coffee drink and time for drying grain.

\section{MATERIAL AND METHODS}

The study was conducted at Lavrinha farm at Poços Fundo- South of Minas Gerais, located between the geographic coordinates latitude $21^{\circ} 44^{\prime} 13^{\prime \prime} S$, longitude $46^{\circ} 03^{\prime} 54^{\prime \prime O}$. Summer presents higher rainfall than winter being classified as Cwb according to Köppen and Geiger. The average annual temperature is $20.4{ }^{\circ} \mathrm{C}$ and the average annual rainfall is 1497 $\mathrm{mm}$, according to the Clima-Date. $\mathrm{Org} /{ }^{1}$ website.

The selected coffee plot was implanted in February 2017 with the species Coffea arabica, cultivar Catuaí red IAC 144 , a spacing of $3.00 \times 1.30 \mathrm{~m}, 2,564$ plants ha $^{-1}$, harvesting was performed manually and selectively when the fruits had an average maturation of $80 \%$.

To compose the plots the harvested coffee was separated and placed in a concrete yard at 800 meters altitude on the same property, each plot had about 20 liters of parchment coffee piled with approximately $30 \mathrm{~cm}$ high and $60 \mathrm{~cm}$ in diameter. To control fermentation, the temperature $\left({ }^{\circ} \mathrm{C}\right)$ was monitored with an infrared thermometer and the time (hours), according to the following treatments:

- Treatment 1: piled coffee being monitored until it reaches a temperature of $30^{\circ} \mathrm{C}$ and remaining piled for 1 hour;

- Treatment 2: piled coffee monitored until $30^{\circ} \mathrm{C}$ and remaining piled for 2 hours;

- Treatment 3: piled coffee monitored until $30^{\circ} \mathrm{C}$ and remaining piled for 3 hours;

- Treatment 4: piled coffee monitored until $30^{\circ} \mathrm{C}$ and remaining piled for 6 hours;

- Treatment 5: piled coffee monitored until $30^{\circ} \mathrm{C}$ and remaining piled for 12 hours;

- Treatment 6: piled coffee monitored until $30^{\circ} \mathrm{C}$ and remaining piled for 24 hours;

- Treatment 7: piled coffee monitored until $40{ }^{\circ} \mathrm{C}$ and remaining piled for 1 hour;

- Treatment 8: piled coffee monitored until $40^{\circ} \mathrm{C}$ and remaining piled for $r$ hours;

- Treatment 9: piled coffee monitored until $40{ }^{\circ} \mathrm{C}$ and remaining piled for $r$ hours;

- Treatment 10: piled coffee monitored until $40{ }^{\circ} \mathrm{C}$ and remaining piled for 6 hours;

- Treatment 11 , piled coffee monitored until $40^{\circ} \mathrm{C}$ and remaining piled for 12 hours;
- Treatment 12 piled coffee monitored until $40{ }^{\circ} \mathrm{C}$ and remaining piled for 24 hours.

Control treatment: coffee harvested and the drying process started in a conventional way.

The treatments were installed with three replications per treatment in a randomized block system (DBC) in a $2 \times 6$ factorial scheme (temperature $\mathrm{x}$ time) plus the control control treatment with 20 liters of coffee per plot. Totaling 39 experimental plots and approximately 800 liters of parchment coffee.

After reaching the temperature and time of fermentation time the plots were spread and the drying process started, according to the methodology recommended by Borém (2008). At the end of the drying process when the treatments (coffee) reached $11.5 \%$ of humidity, it was bagged and taken to rest for 15 days and then processed. The samples were sent for sensory analysis in COOPFAM quality laboratory, evaluating the type of coffee, punctuation, aroma and the drink by the SCAA (2015) methodology.

Data were submitted to analysis of variance by Scott Knott's test at 5\% using SISVAR ${ }^{\circledR}$ program (Ferreira 2014).

\section{RESULTS AND DISCUSSION}

With the results obtained after coffee processing, the quality evaluation according to the SCCA methodology and the data evaluated by the analysis of variance, we can observe the importance of using new methodologies for harvesting and drying coffee.

Table 1 shows the results obtained by temperature and time induced fermentation, where there was an increase in quality according to SCAA scores. Control treatment highlights the need for process improvement to correlate with a higher quality. Treatments where coffee was stimulated to controlled fermentation at $30^{\circ} \mathrm{C}$ did not differ statistically.

Regarding treatments based on fermentation time, there was a slight variation in the results of treatments $1\left(30{ }^{\circ} \mathrm{C}\right.$ for 1 hour) and $3\left(30^{\circ} \mathrm{C}\right.$ for 3 hours), presenting some differences in the score. For the $40{ }^{\circ} \mathrm{C}$ treatments, a significant change was observed in the score of the fermented coffees at $30^{\circ} \mathrm{C}$. Especially in treatments 7 (at $40^{\circ} \mathrm{C}$ for 1 hour), $9\left(40{ }^{\circ} \mathrm{C}\right.$ for 3 hours) and 12 (40 ${ }^{\circ} \mathrm{C}$ for 24 hours).

Abreu et al (2019) found similar results after using drying methods of natural fermentation and fermentation with pulped coffee, with the varieties Catiguá MG 2 and Híbrido 419-4, reachinga score above 85 points, emphasizing the importance of carrying out methods post harvest to increase quality.

Anaerobic fermentation methodology with waterpulped and submerged coffees, controlled by time, temperature and humidity, shows that the coffee that did not have the presence of water obtained a better result compared to the 
one that had the presence of water in the fermentation. When coffee was kept for 48 hours at $10{ }^{\circ} \mathrm{C}$ and $25^{\circ} \mathrm{C}$ obtained 80 points (Rodrigues, 2017).

Table 1: Beverage quality of fermented coffees based on SCAA rating.

\begin{tabular}{cccc}
\hline Treatments & Temperature $\left({ }^{\circ} \mathrm{C}\right)$ & Time (hours) & Grade \\
\hline Control & - & - & $82.0 \mathrm{Cc}$ \\
1 & 30 & 1 & $83.3 \mathrm{Ba}$ \\
2 & 30 & 2 & $82.8 \mathrm{Bb}$ \\
3 & 30 & 3 & $83.0 \mathrm{Ba}$ \\
4 & 30 & 6 & $82.7 \mathrm{Bb}$ \\
5 & 30 & 12 & $82.9 \mathrm{Bb}$ \\
6 & 30 & 24 & $82.6 \mathrm{Bb}$ \\
7 & 40 & 1 & $84.0 \mathrm{Aa}$ \\
8 & 40 & 2 & $82.9 \mathrm{Bb}$ \\
9 & 40 & 3 & $84.1 \mathrm{Aa}$ \\
10 & 40 & 6 & $82.8 \mathrm{Bb}$ \\
11 & 40 & 12 & $82.7 \mathrm{Bb}$ \\
12 & 40 & 24 & $84.0 \mathrm{Aa}$ \\
\hline
\end{tabular}

* Means followed by the same letter in column do not differ by Scott Knott's test at $5 \%$ probability.

The drying time or dehydration of the beans are limiting factors for obtaining quality coffees. According to Ribeiro (2012), the coffee drying period is directly influenced by the conditions and microclimates of each region. The results in Table 2 indicate that the control treatment and the $40{ }^{\circ} \mathrm{C}$ treatment were longer, obtaining statistically better results.

Table 2: Drying time of fermented coffees in concrete yard, until reaching $11.5 \%$ humidity.

\begin{tabular}{cccc}
\hline Treatments & Temperature $\left({ }^{\circ} \mathrm{C}\right)$ & Time (hours) & Days \\
\hline Control & - & - & $64.5 \mathrm{Aa}$ \\
1 & 30 & 1 & $62.0 \mathrm{Bb}$ \\
2 & 30 & 2 & $61.3 \mathrm{Ba}$ \\
3 & 30 & 3 & $61.3 \mathrm{Ba}$ \\
4 & 30 & 6 & $61.3 \mathrm{Ba}$ \\
5 & 30 & 12 & $61.3 \mathrm{Ba}$ \\
6 & 30 & 24 & $61.3 \mathrm{Ba}$ \\
7 & 40 & 1 & $64.0 \mathrm{Aa}$ \\
8 & 40 & 2 & $64.0 \mathrm{Aa}$ \\
9 & 40 & 3 & $64.0 \mathrm{Aa}$ \\
10 & 40 & 6 & $63.3 \mathrm{Aa}$ \\
11 & 40 & 12 & $63.0 \mathrm{Ab}$ \\
12 & 40 & 24 & $63.0 \mathrm{Ab}$ \\
\hline
\end{tabular}

*Means followed by the same letter in column do not differ by Scott Knott's test at $5 \%$ probability.
Table 2 shows the results where the control, as it did not undergo any fermentation treatment, resulted in a longer drying process time. The treatments with temperature at $30^{\circ} \mathrm{C}$ did not presented differences in drying time, even to the time difference (hours). For the $40{ }^{\circ} \mathrm{C}$ temperature treatments, we can observe a significant difference in the treatments for 12 and 24 hours, resulting in shorter drying time compared to the others.

Coradi et al. (2008) presented interesting results in relation to different drying methods using the terrace and vertical dryer, the Best results obtained were in relation to the temperature of $60{ }^{\circ} \mathrm{C}$ in drying in the terrace and being stored for 90 to 180 days

Regarding the waiting time for the start of the fermentation, Table 3 presents some relevant results that were obtained in this research. Table 3 shows that the treatments with fermentation controlled by temperature at $30{ }^{\circ} \mathrm{C}$ did not differ statistically. Treatments with temperature at $40{ }^{\circ} \mathrm{C}$ presented some differences, being the treatments 7 and 9 the ones that provided the best drying time results.

Table 3: Time to reach temperature for fermentation start at temperatures $\left(30\right.$ and $\left.40^{\circ} \mathrm{C}\right)$.

\begin{tabular}{cccc}
\hline Treatments & Temperature $\left({ }^{\circ} \mathrm{C}\right)$ & Time (hours) & Minutes \\
\hline Control & - & - & - \\
1 & 30 & 1 & $1213 \mathrm{Dd}$ \\
2 & 30 & 2 & $1198 \mathrm{Dd}$ \\
3 & 30 & 3 & $1174 \mathrm{Dd}$ \\
4 & 30 & 6 & $1132 \mathrm{Dd}$ \\
5 & 30 & 12 & $1098 \mathrm{Dd}$ \\
6 & 30 & 24 & $1127 \mathrm{Dd}$ \\
7 & 40 & 1 & $4109 \mathrm{Aa}$ \\
8 & 40 & 2 & $3592 \mathrm{Bb}$ \\
9 & 40 & 3 & $4079 \mathrm{Aa}$ \\
10 & 40 & 6 & $3306 \mathrm{Bb}$ \\
11 & 40 & 12 & $2840 \mathrm{Cc}$ \\
12 & 40 & 24 & $3300 \mathrm{Bb}$ \\
\hline
\end{tabular}

* Means followed by the same letter in column do not differ by Scott Knott's test at $5 \%$ probability.

Figure 1 indicates the attributes (fragrance and flavors) found in the sensory analysis, according to the classification methodology SCAA (2015), for specialty coffees. Most of the attributes found refer to chocolate, honey, citrus, caramel and fruity, all treatments presented these attributes. We can verify the difference of attributes presented by the control treatment to the other treatments of temperature with $30{ }^{\circ} \mathrm{C}$ and $40{ }^{\circ} \mathrm{C}$, and of time with 1 hour, 2 hours, 3 hours, 6 hours, 12 hours and 24 hours, obtaining a great variety of attributes. 


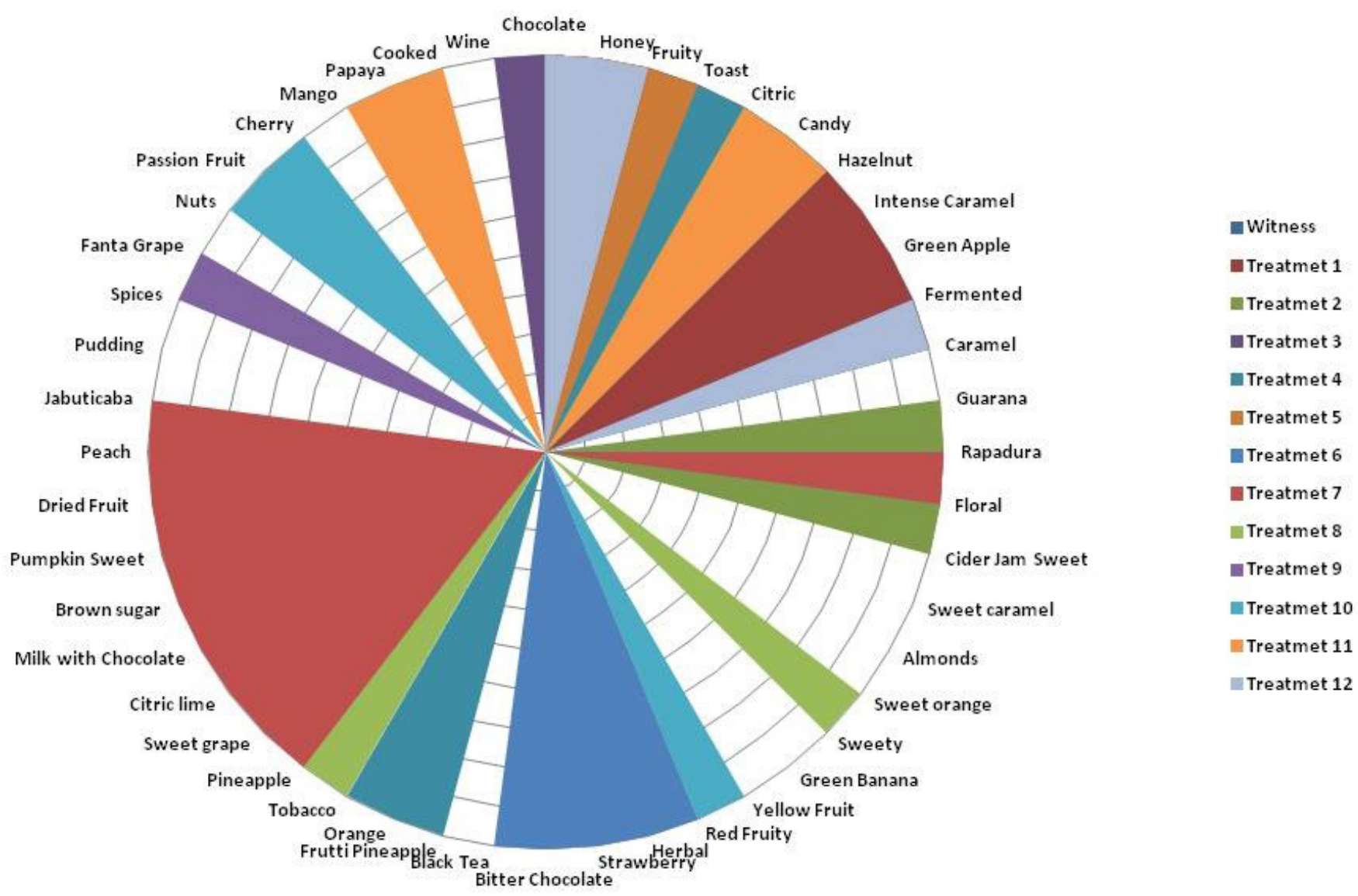

Figure 1: Beverage quality atributes of browed coffees based on SCAA classification.

It is worth mentioning that the fermented coffees included aromas such as: fruity, floral, wine, herbal, tobacco, sweet, neutral and citrus and different flavors such as: chocolate, strawberry, honey, caramel, green banana, green apple, papaya, peach, mango, berries, yellow fruits, pineapple, dark chocolate, jabuticaba, spices, rapadura, hazelnut, walnuts, fermented, cherry, pudding, black tea, pumpkin jam, cider jam, almonds, chocolate milk, brown sugar, sweet grape , grape fanta, orange candy and passion fruit.

In the methodology used by Araujo (2018), the results of some attributes are similar. However, most of the results presented in the research were related to yellow fruits, red fruits, vanilla cocoa, citrus fruits, and caramelized sugar. In this case, it is noted that it did not obtain a great variation of the sensorial characteristics. All treatments presented the same results to the anaerobic fermentation methodology, being induced and controlled for 12 hours, 24 hours and 36 hours.

\section{CONCLUSIONS}

Natural fermentation induced by temperature $\left({ }^{\circ} \mathrm{C}\right)$ and time (hours) control, directly influenced the quality of the drink, resulting in a coffee with a score of 82 to 84 points, with attribute aggregation and Special rating, according to the SCAA classification (2015). Natural fermentation monitored until $40{ }^{\circ} \mathrm{C}$ by 1,3 e 24 hours, resulted in coffee with better quality, with 84 points and an increase in the sensorial attributes.

This study is essential and highlights the importance of conducting a selective harvest to contribute to obtaining specialty coffees. We also emphasize that such research should be conducted for the next harvests in different microclimates and coffee regions so that a methodology regarding the natural fermentation controls by time and temperature can be defined in the future.

\section{ACKNOWLEDGEMENTS}

The authors would like to thank the Machado Higher Education and Research Center - CESEP, and the Family Farmers Cooperative of Poço Fundo e Region - COOPFAM, for their contribution to this research.

\section{REFERENCES}

ABREU, G. F de, et al. Sensory potential of modern arábica coffee genotypes subjected to nwe wet processes. 2019. Available in: < http://www. consorciopesquisacafe.com.br/ojs/index.php/ SimposioCafe2019/article/view/456/288>. Access in: 22 april 2020. 
ALESSANDRO, S. C. D. Identification of Special Coffees. In: SAKIYAMA, N. et al (Ed). Arabica Coffee: from Planting to Harvest. Viçosa, MG: publishing company UFV, 2015, p. 268-291.

BORÉM, F. M. et al. Quality of natural and pulped coffee after drying on a terrace and with high temperatures. Ciência e Agrotecnologia, 32(5):1609-1615, 2008.

BORÉM, F. M. et al. Quality of coffee subjected to different temperatures, air flows and pre-drying periods. Coffee Science, 1(1):55-63, 2006

CHALFOUN, S. M.; FERNANDES, A. P. Effects of fermentation on the quality of the coffee drink. Agricultural Vision, Piracicaba SP, 12:105-108, 2013. Available in: < https://www.esalq.usp.br/visaoagricola/ sites/default/files/va12-qualidade-da-bebida01.pdf $>$. Access in: 18 aug. 2019.

CORADI, P. C.; BOREM, F. M.; OLIVEIRA, J. A. Quality of natural and pulped coffee after different types of drying and storage. Brazilian Journal of Agricultural and Environmental Engineering, Campina Grande PB, 12(2):181-188, 2008.: Available in <http://www.scielo.br/ pdf/rbeaa/v12n2/v12n02a11.pdf $>$. Access in: 22 april 2020.

FERREIRA, D. F. Sisvar: A guide to your Bootstrap multiple comparison procedures. Ciência e Agrotecnologia, 38(2):109-102, 2014.

MALTA, M. R. et al. Coffee Harvest and Post-Harvest: Recommendations and Technical Coefficients. Agricultural Report, 29(247):84-128, 2008.

MINISTRY OF AGRICULTURE - MAPA, Livestock and Supply of Brazil; Coffee in Brazil. 2018. Available in;< https://www.gov.br/agricultura/pt-br/assuntos/politicaagricola/cafe/cafeicultura-brasileira $>$. Access in: 24 aug. 2019.

PIMENTA, C. J. Effect of type and time of harvest on coffee quality (Coffea arabica L). Acta Scientiarum: Agronomy, 25(1):131-136, 2003

RIBEIRO, C. L. Care in drying natural coffee on a terrace. 2012. Available in $<$ https://revistacafeicultura.com.br/ index.php?tipo $=$ ler\&mat $=45178>$. Access in: 06 nov. 2019.

RODRIGUES, G. Z. et al. Evaluation of the controlled fermentation process of coffee under different conditions of time, temperature and humidity. 2017. n.43, Poços de Caldas- MG, Foundation Procafé p.187-188 Available in < http://www.sbicafe.ufv.br/ bitstream/handle/123456789/9424/187_43-CBPC-2017. pdf? sequence=1>. Access in: 25 out. 2019 .

RUFINO, J. L. dos S.; SILVA, M. A. da. Commercialization. In: SAKIYAMA, N. et al (Ed). Arabica Coffee: from planting to harvest. Viçosa, MG: publishing company UFV. 2015, p. 292-316.

SPECALTY COFFEE ASSOCIATION OF AMERICASCAA. Cupping Specialty Coffee Published by the Specialty Coffee Association of America Rev: Dez 16, 2015. available in <https://www.scaa.org/PDF/ resources/cupping-protocols.pdf $>$ Access in: 30 out. 2019.

TEIXEIRA, M. M.; LARCEDA FILHO, A. F. et al. Harvest and Post-Harvest. In: SAKIYAMA, N. et al (Ed).

Arabica Coffee: from planting to harvest. Viçosa, $\mathrm{MG}$ : publishing company UFV. 2015, p. 216-249. 